\title{
306 リングバースト試験を用いた CFRP リングの疲労強度評価 Evaluation of Fatigue Strength of CFRP Ring using Ring Burst Test
}

\author{
○正 小林 訓史(都立大), 正 若山 修一(都立大), \\ 茂木 佳祐(都立大), 山口 祥吾(都立大) \\ Satoshi KOBAYASHI,Shuici WAKAYAMA,Keisuke MOGI,Syogo YAMAGUCHI \\ Tokyo Metropolitan University, 1-1 Minami-Ohsawa,Hachioji-shi, Tokyo 192-0397
}

\begin{abstract}
The ring burst test equipment developed by one of the authors was used to evaluate the fatigue strength of FW-FRP ring specimens in the hoop direction. In the new equipment, flat cage (needle bearings) were used to reduce the friction between the rod and the segments The specimens used were T700S/epoxy, CFRP rings. During the fatigue tests, matrix cracking at the surface resin rich layer and delamination from the tips of the matrix cracks were observed. This behavior is similar to the damage progress in the FRP pressure vessels. It is proved that the present test system was available for estimating the fatigue strength of the FRP pressure vessels in the hoop direction.
\end{abstract}

Key Words : Ring Burst Test, Fatigue Strength, FW-FRP composite

\section{1. 緒言}

近年, 圧力容器軽量化のために, FW-FRP (Filament Wound Fiber Reinforced Plastics) 複合圧力容器が様々な方面で用いら れてきている。しかしながら, FW-FRP 複合圧力容器そのも のの内圧試験のコストが多大であることから，圧力容器で特 に重要であるフープ (円周) 方向の簡便強度評価法としてリ ングバースト試験が近年開発されてきた(1). 本研究ではべア リングを設置することにより各部の摩擦を低減した改良型リ ングバースト試験法 ${ }^{(2)}$ を用いて FW-FRP リング試験片に対し て疲労試験を行い，本試験法による疲労強度評価法の確立を 目的とする.

\section{2. 実験方法}

\section{1 試験片}

本研究で使用した材料は強化緎維として T700SC-24K（東 レ), マトリックスとしてエポキシ樹脂を用いた炭素瀻維強化 プラスチック (CFRP) リングである. マトリックスとしては 主剤に Epikote828 (ジャパンエポキシレジン), 硬化剤に HN2200（日立化成）, 硬化促進剤にジメチルベンジルアミン （花王）をそれぞれ重量比で 100:80:1 に混合したものを用い た、繊維をレジンバスに通すことにより樹脂を含浸させ，離 形処理した直径 96 ミリのアルミニウム製マンドレルに 5 層巻 きつけた。その後マンドレルを炬内にて $100^{\circ} \mathrm{C} 1$ 時間, $150^{\circ} \mathrm{C}$ 4 時間回転保持することにより,マトリックスを硬化させた． 硬化後マンドレルを抜き，ダイヤモンドカッターにて幅 $10 \mathrm{~mm}$ に切り出した。試験片端面はサンドペーパーにて 2000 番まで研磨を行った。試験片形状を Fig. 1 に示す.

\section{2 リングバースト試験}

Fig. 2 に改良型リングバースト試験用治具の模式図を示す. 本治具の各接触部分にはフラットケージ（ニードルベアリン グ）が配置され，摩擦を軽減している、テーパのついたロッ ドを台座の上に置かれた 12 分割されたセグメントに挿入す ることにより，ウレタンゴムを介してリング状試験片に内压 を模擬的に作用させる．軸力-内圧換算式は，校正リングとし てモリブデン鋼を用いたときの軸力-ひずみ線図から，

$\mathrm{P}[\mathrm{MPa}]=4.14 \mathrm{~F}[\mathrm{kN}]$

で与えられることが確認されている。

以上の治具を油圧式疲労試験機に装着し，荷重制御にて室 温・大気中で疲労試験を行った. 試験条件は正弦波, 繰返し周 波数 $5 \mathrm{~Hz}$, 応力比 0.05 である.

\section{4. 実験結果および考察}

Fig. 3 にリング試験片の端面観察より得られた疲労損傷を 示す. 最初に観察される微視的損傷は試験片表面の樹脂リッ チ層におけるマトリックスクラックである.このクラックは 発生と同時に試験片幅方向に貫通し，繰り返し数の増加とと もに厚さ方向に進展する．マトリックスクラックが CFRP 層 まで達すると，樹脂リッチ層/CFRP 層間におけるはく離がマ トリックスクラック先端より生じ, 繰り返し数の増加ととも に層間に沿って進展する。この際，はく離先端が CFRP 層の 䋐維に沿った方向に分岐して進展していく部分もあり，最終 的にはこれらのクラックを起点としてスプリッティング破壊 が生じた。

本実験から得られた破断繰り返し数と最大内圧の関俰を Fig. 4 に示す. 本研究で用いた材料系においては明確な疲労限 
は確認されなかったが, 最大内圧が約 $17 \mathrm{MPa}$ 以下になると急 激に破断繰り返し数が増大することが確認された。また，試 験結果にばらつきに少ないことからも，本試験法によって， フープ方向の疲労強度を評価することが可能であることが確 認された。

5. 結言

改良型リングバースト試験法を用いて FW-CFRP リングの疲 労試験を行い, 以下の結論を得た。

（1）疲労負荷過程で最初に観察される微視的損傷は, 表面の 樹脂リッチ層におけるマトリックスクラックであり，これが はく離やスプリッティングを引き起こす原因となる。

(2) 試験結果にばらつきが少ないことから，本試験法によっ て FW-FRP 複合圧力容器のフープ方向疲労強度を評価するこ とが可能である。

\section{参考文献}

(1) A. Horide, et al., Adv. Compos. Mater., 8:139 (1999).

(2) S. Wakayama, et al., Submitted to Compos. Sci. and Technol.

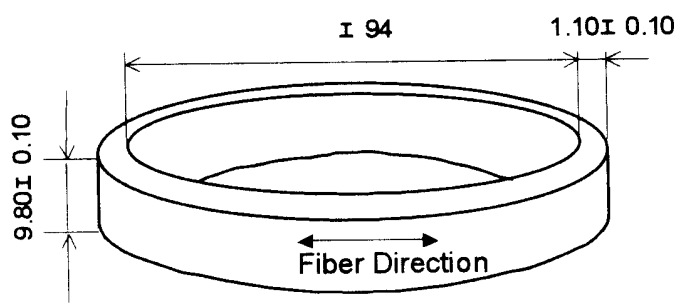

Figure 1 Specimen geometry

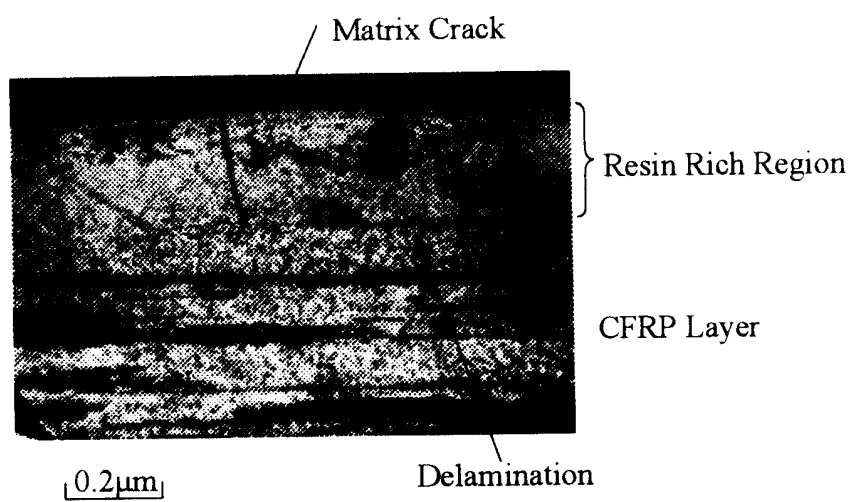

Figure 3 Microscopic damage progress during fatigue tests.

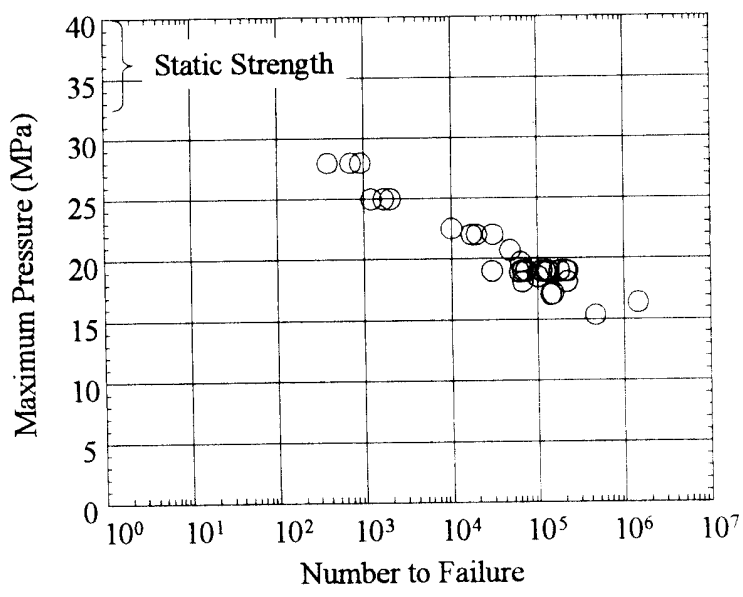

Fig. 4 Relation between number to failure and maximum internal pressure.

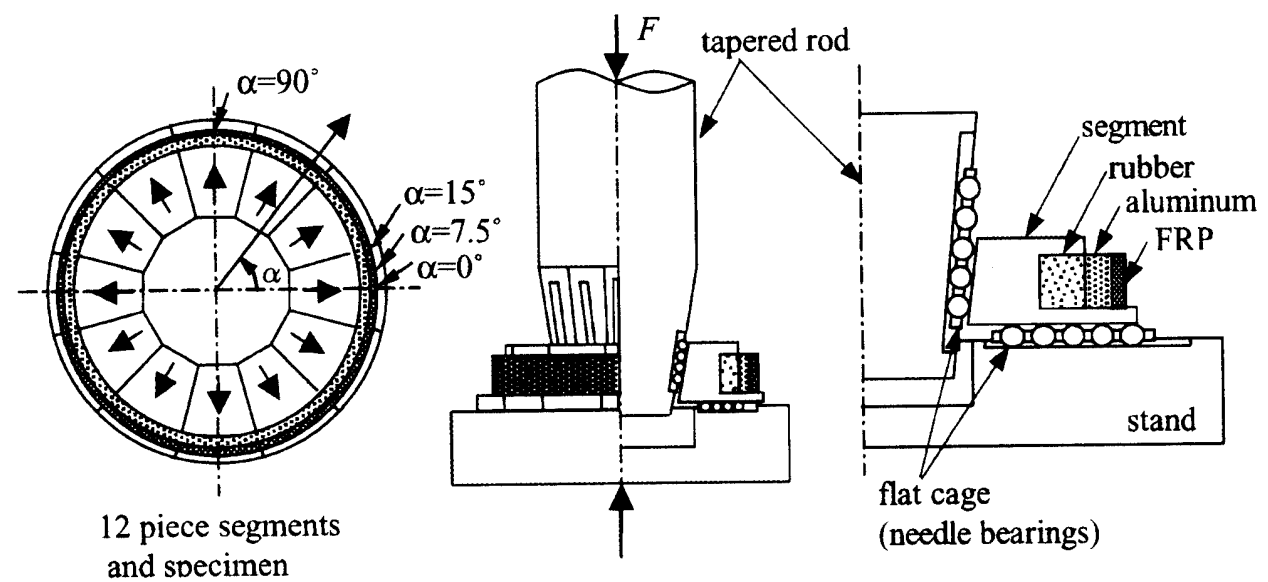

Figure 2 Schematics of new equipment of ring burst test. 